\title{
Estimation of progesterone in buffalo milk and its application to pregnancy diagnosis
}

\author{
A. Singh and R. Puthiyandy \\ National Dairy Research Institute, Karnal 132001, India
}

\begin{abstract}
Summary. Milk samples were collected on Days 20, 24, 28 and 40 after insemination. The percentage of fat and the progesterone concentration in the milk were correlated $(P<0.01)$. Progesterone concentration in the milk of pregnant buffaloes $(24.83 \pm 3.85 \mathrm{ng} / \mathrm{ml})$ was significantly higher than that in non-pregnant animals $(2.89 \pm 1.25 \mathrm{ng} / \mathrm{ml})$ on Day 20 and the difference between the two increased with time after insemination. The detection of non-pregnant animals was $100 \%$ successful at all times but the diagnosis was correct for $66,68,81$ and $83 \%$ of animals tested on Days $20,24,28$ and 40 respectively and predicted as pregnant.
\end{abstract}

\section{Introduction}

Since the report that progesterone can be measured in cow milk (Heap \& Linzell, 1966; Heap, Linzell \& Slotin, 1969; Heap, Bedford \& Linzell, 1975), there has been much research to evolve a precise and quick method for the estimation of progesterone in milk and to correlate the values with the reproductive state of the cow. Laing \& Heap (1971) first reported that progesterone concentration in milk might provide a method for early pregnancy diagnosis. Heap, Gwyn, Laing \& Walters (1973) proposed the use of radioimmunoassay of progesterone without ether extraction as a rapid method of measuring progesterone in milk and many workers have now established that the progesterone concentration in the milk of cows can be used to detect animals in pregnancy (Thibier, 1974; Schiavo, Matuszczak, Oltenacu \& Foote, 1975; Heap, Holdsworth, Gadsby, Laing \& Walters, 1976; Pennington, Spahr \& Lodge, 1976; Pope, Majzlik, Ball \& Leaver, 1976; Lamming \& Bulman, 1976; Laing, 1976; Dobson \& Fitzpatrick, 1976). Almost all these workers have suggested that accurate diagnosis of pregnancy is possible at 21-24 days after mating.

There appears to be no report available on the progesterone concentration in the milk of buffaloes and the aim of the present study was to measure progesterone concentrations in buffalo milk and correlate it with the state of pregnancy.

\section{Materials and Methods}

\section{Samples}

Murrah buffaloes (Bubalus bubalis) were chosen for this study from the herd maintained at this Institute. Such buffaloes have an oestrous cycle of about 21 days.

Samples of first milk and full milk were initially collected at the morning $(05: 00 \mathrm{~h})$ and evening (18:30 h) milking on Days 20, 24 and 28 after artificial insemination. The animals were inseminated, with $1 \mathrm{ml}$ semen containing 50-100 $\times 10^{6}$ spermatozoa, 12-18 h after the start of oestrus. Subsequent samples of full milk were collected at the evening milking only on Days 20 , 24, 28 and 40 and stored in a deep freeze. 
Assay

The antiserum to progesterone was prepared in rabbits against progesterone-11 $\beta$-succinylbovine serum albumin and was obtained as a freeze-dried powder from New England Nuclear (Boston, Massachusetts). The cross-reactions of the antiserum with other hormones (progesterone $100 \%$ ) were reported to be as follows: 17 -hydroxyprogesterone, $4.3 \% ; 16 \alpha$ hydroxyprogesterone, $1.3 \% ; 20 \alpha$-dihydroprogesterone, $0.6 \%$; pregnenolone, 11 -deoxycortisol and testosterone, $0 \cdot 1 \%$; and cortisol $<0 \cdot 1 \%$.

Another antiserum, subsequently obtained from Dr B. V. Clifton (I.C.I. Cheshire, England), was raised in a goat immunized against progesterone $11 \alpha$-succinyl-bovine serum albumin. The cross-reactions with other hormones (progesterone $100 \%$ ) were as follows: $11 \alpha$-hydroxypregn-4en-3,20-dione 177\%; $11 \beta$-hydroxypregn-4-en-3,20-dione, 35\%; deoxycorticosterone, $12.5 \%$; corticosterone, $3.8 \%$; $5 \beta$-pregnane-3,20-dione, $2.5 \%$; oestradiol-17 $\beta, 0.7 \%$; 16 $\alpha$-hydroxyprogesterone, $0.5 \% ; 20 \beta$-hydroxypregn- 4 -en- 3 one, $0.2 \%$ and other steroids $<0.1 \%$.

The assay for progesterone was essentially as described by Heap et al. (1976). The collected milk samples were thawed to room temperature and $20 \mu \mathrm{l}$ were pipetted into a $7 \mathrm{ml}$ glass testtube and diluted with $500 \mu \mathrm{l}$ of $0.1 \mathrm{M}$-phosphate buffer $\left(3.04 \mathrm{~g} \mathrm{NaH}_{2} \mathrm{PO}_{4} \cdot 2 \mathrm{H}_{2} \mathrm{O}, 5.43 \mathrm{~g}\right.$ $\mathrm{Na}_{2} \mathrm{HPO}_{4} \cdot 2 \mathrm{H}_{2} \mathrm{O}, 4.5 \mathrm{~g} \mathrm{NaCl}, 0.5 \mathrm{~g} \mathrm{NaN}_{3}$ and $0.5 \mathrm{~g}$ gelatin in $500 \mathrm{ml}$ distilled water) adjusted to $\mathrm{pH} 7.0$ with $1 \mathrm{~N}-\mathrm{NaOH}$.

The progesterone antiserum was made up in $100 \mu \mathrm{l} 0 \cdot 1 \mathrm{M}$-phosphate buffer and added. The dilution of antiserum used was sufficient to bind $30-40 \%$ of 20000 d.p.m. $\left[1,2,6,7-{ }^{3} \mathrm{H}\right]$ progesterone (sp. act. $97.9 \mathrm{Ci} / \mathrm{mmol}$; New England Nuclear). The tubes were incubated at $16-18^{\circ} \mathrm{C}$ for $30 \mathrm{~min}$. Then another $100 \mu \mathrm{l}\left[1,2,6,7-{ }^{3} \mathrm{H}\right]$ progesterone $(20000 \mathrm{~d}$.p.m.) in phosphate buffer were added and vortexed. The samples were then incubated at $4^{\circ} \mathrm{C}$ for $14-18 \mathrm{~h}$. The reaction was terminated by placing the tubes in crushed ice. After incubation, $1 \mathrm{ml}$ charcoal suspension containing $250 \mathrm{mg}$ Norit A charcoal (ICN Pharmaceuticals Inc., Cleveland, Ohio) and $25 \mathrm{mg}$ dextran $\mathrm{T}-70 / 100 \mathrm{ml} 0.1 \mathrm{M}$ phosphate buffer was added and the mixture centrifuged at $4{ }^{\circ} \mathrm{C}$. Then $0.5 \mathrm{ml}$ supernatant was transferred to counting vials and $10 \mathrm{ml}$ toluene-Triton $\mathrm{X}-100(2: 1$ $\mathrm{v} / \mathrm{v}$ ) scintillation fluid were added. The radioactivity was measured in a Scintillation spectrometer (Model 3330, Packard Tri-Carb) for $1 \mathrm{~min}$.

For the standard curve, progesterone (Sigma Chemical Co., St. Louis, U.S.A.) was dissolved in distilled alcohol and a small measured fraction was dried under nitrogen, dissolved in phosphate buffer and serially diluted to provide $0,0.1,0.2,0.4,0.8,1.0,2.0$ and $4.0 \mathrm{ng}$ samples in $0.5 \mathrm{ml}$ buffer. These samples were mixed in $20 \mu \mathrm{l}$ milk collected from a non-pregnant non-cyclic buffalo, the milk of which contains little or no progesterone, and treated in the same way as samples being tested. The corresponding binding percentages were $37 \cdot 1,27 \cdot 0,26 \cdot 1$, $18 \cdot 6,17 \cdot 2,15 \cdot 0,12 \cdot 1$ and $9 \cdot 8$. The progesterone values for the unknown samples were obtained by interpolation from the standard curve. A zero standard without any progesterone and a blank excluding antiserum were also included in each assay run. The sensitivity of the assay was 0.5 $\mathrm{ng} / \mathrm{ml}$.

\section{Estimation of fat}

Milk fat was estimated by the Gerber method described by the Indian Standards Institution (1958).

\section{Results}

\section{Progesterone in first and full milk samples}

The results for pregnant and non-pregnant buffaloes are shown in Table 1. In all the pregnant animals, milk progesterone concentrations and fat content were significantly higher in the full-milk than in the first-milk samples (Table 2). Evening values were consistently higher 
than those for morning samples and the difference was significant (Table 2). There was a significant $(P<0.01)$ correlation between milk progesterone concentration and fat content for all samples except that for evening full milk on Day 28. In the non-pregnant animals the full-milk fat values were significantly higher than those for first-milk samples (Table 2), but the differences for the progesterone concentrations were not as great as for pregnant buffalo cows. There was a significant correlation $(P<0.01)$ between milk fat and progesterone level for all samples except that for morning full milk on Day 28.

Table 1. Mean \pm s.e.m. progesterone concentration $(\mathrm{ng} / \mathrm{ml})$ and fat in first and full milk taken at the morning and evening milkings from 17 pregnant and 14 non-pregnant buffaloes at different times after insemination

\begin{tabular}{|c|c|c|c|c|c|c|c|}
\hline & \multirow{2}{*}{$\begin{array}{l}\text { Time of } \\
\text { day (h) }\end{array}$} & \multicolumn{2}{|c|}{ Day 20} & \multicolumn{2}{|c|}{ Day 24} & \multicolumn{2}{|c|}{ Day 28} \\
\hline & & First milk & Full milk & First milk & Full milk & First milk & Full milk \\
\hline Pregnant & $\begin{array}{l}05: 00 \\
18: 30\end{array}$ & $\begin{array}{r}9.5 \pm 2.5 \\
11.6 \pm 2.1\end{array}$ & $\begin{array}{l}21 \cdot 0 \pm 3 \cdot 4^{*} \\
25 \cdot 2 \pm 2 \cdot 8^{*}\end{array}$ & $\begin{array}{c}\text { Progesterc } \\
11 \cdot 3 \pm 2 \cdot 9 \\
12 \cdot 4 \pm 2 \cdot 0\end{array}$ & $\begin{array}{l}\text { one }(\mathrm{ng} / \mathrm{ml}) \\
24 \cdot 1 \pm 2 \cdot 8^{*} \\
26 \cdot 1 \pm 3 \cdot 8^{*}\end{array}$ & $\begin{array}{l}19.0 \pm 2.9 \\
21.6 \pm 3.2\end{array}$ & $\begin{array}{l}29.4 \pm 3.9^{*} \\
33.2 \pm 4.2^{*}\end{array}$ \\
\hline Non-pregnant & $\begin{array}{l}05: 00 \\
18: 30\end{array}$ & $\begin{array}{l}0.9 \pm 0.3 \\
1.1 \pm 0.6\end{array}$ & $\begin{array}{l}1.5 \pm 0.9 \\
2.1 \pm 1.3\end{array}$ & $\begin{array}{r}0.98 \pm 0.9 \\
1.2 \pm 0.8\end{array}$ & $\begin{array}{l}1.7 \pm 1.1 \\
2.3 \pm 0.98^{*}\end{array}$ & $\begin{array}{l}1.0 \pm 0.4 \\
1.3 \pm 0.98^{*}\end{array}$ & $\begin{array}{l}1.7 \pm 1.1 \\
2.7 \pm 1.4\end{array}$ \\
\hline & & & & & $t(\%)$ & & \\
\hline $\begin{array}{l}\text { Pregnant } \\
\text { Non-pregnant }\end{array}$ & $\begin{array}{l}05: 00 \\
18: 30 \\
05: 00 \\
18: 30\end{array}$ & $\begin{array}{l}4.5 \pm 0.2 \\
4.7 \pm 0.2 \\
4.2 \pm 0.2 \\
4.2 \pm 0.2\end{array}$ & $\begin{array}{l}8 \cdot 5 \pm 0.3^{*} \\
8.6 \pm 0.3^{*} \\
8.4 \pm 0.4^{*} \\
8 \cdot 5 \pm 0.4^{*}\end{array}$ & $\begin{array}{l}4.5 \pm 0.1 \\
4.5 \pm 0.1 \\
4.9 \pm 0.2 \\
4.3 \pm 0.2\end{array}$ & $\begin{array}{l}8 \cdot 6 \pm 0.3^{*} \\
8.6 \pm 0.3^{*} \\
8.7 \pm 0.3^{*} \\
8.6 \pm 0.3^{*}\end{array}$ & $\begin{array}{l}4.3 \pm 0.2 \\
4.6 \pm 0.1 \\
4.2 \pm 0.2 \\
4.4 \pm 0.1\end{array}$ & $\begin{array}{l}8.4 \pm 0.2^{*} \\
8.6 \pm 0.2^{*} \\
8.7 \pm 0.4^{*} \\
8.7 \pm 0.3^{4}\end{array}$ \\
\hline
\end{tabular}

* Significantly different from corresponding first milk sample $P<0.01$.

Table 2. Analysis of variance of fat and progesterone values of pregnant and non pregnant buffaloes

\begin{tabular}{|c|c|c|c|c|c|c|c|c|c|c|}
\hline \multirow{3}{*}{$\begin{array}{l}\text { Source of } \\
\text { variation }\end{array}$} & \multirow[b]{3}{*}{ d.f. } & \multicolumn{4}{|c|}{ Pregnant buffaloes } & \multirow[b]{3}{*}{ d.f. } & \multicolumn{4}{|c|}{ Non-pregnant buffaloes } \\
\hline & & \multicolumn{2}{|c|}{$\begin{array}{l}\text { Progesterone } \\
\text { concentration }\end{array}$} & \multicolumn{2}{|c|}{ Fat $\%$} & & \multicolumn{2}{|c|}{$\begin{array}{l}\text { Progesterone } \\
\text { concentration }\end{array}$} & \multicolumn{2}{|c|}{ Fat $\%$} \\
\hline & & M.S.S. & F value & M.S.S. & $F$ value & & M.S.S. & F value & M.S.S. & F value \\
\hline $\begin{array}{l}\text { Among } \\
\text { replicates }\end{array}$ & 16 & 7.98 & $2.45^{* *}$ & 1.96 & $3.29^{* *}$ & 13 & 0.30 & 1.77 & 8.92 & $49 \cdot 37^{* *}$ \\
\hline Among times & 1 & 207.03 & $63.62^{* *}$ & $3 \cdot 34$ & $5 \cdot 60^{*}$ & 1 & 10.32 & $60 \cdot 33^{m *}$ & 0.23 & 1.27 \\
\hline Among periods & 2 & 1224.93 & $376.43^{* *}$ & 0.31 & $5 \cdot 14^{*}$ & 2 & $1 \cdot 27$ & $7.41^{* *}$ & 0.54 & 2.97 \\
\hline $\begin{array}{l}\text { Among types } \\
\text { of milk }\end{array}$ & 1 & $7316 \cdot 30$ & $2248 \cdot 39^{* *}$ & $849 \cdot 54$ & $1423 \cdot 94^{* *}$ & 1 & 34.92 & $203 \cdot 20^{* *}$ & $780 \cdot 02$ & $4313 \cdot 43^{* *}$ \\
\hline \multicolumn{11}{|l|}{ Interactions } \\
\hline $\begin{array}{r}\text { Timings } \times \\
\text { periods }\end{array}$ & 2 & 17.00 & $5 \cdot 23^{*}$ & 0.23 & 0.38 & 2 & 0.29 & 1.67 & 0.03 & 0.15 \\
\hline $\begin{array}{l}\text { Timings } \times \\
\text { type of milk }\end{array}$ & 1 & $7 \cdot 74$ & $2 \cdot 38$ & 0.26 & 0.44 & 1 & 2.95 & $17 \cdot 18^{* *}$ & 0.20 & $1 \cdot 10$ \\
\hline $\begin{array}{l}\text { Periods } \times \\
\text { type of milk }\end{array}$ & 2 & 48.07 & $14 \cdot 77^{* *}$ & 0.03 & 0.06 & 2 & 0.18 & 1.07 & 0.12 & 0.65 \\
\hline $\begin{array}{l}\text { Timings } \times \\
\text { periods } x \\
\text { type of milk }\end{array}$ & 2 & 7.51 & $2 \cdot 31$ & 0.001 & 0.016 & 2 & 0.07 & $4 \cdot 20^{*}$ & 0.002 & 0.11 \\
\hline Error & 176 & $3 \cdot 25$ & - & 0.59 & - & 143 & 0.17 & - & 0.18 & - \\
\hline
\end{tabular}

$* P<0.05$.

** $P<0.01$.

\section{Progesterone levels in pregnant and non-pregnant animals}

The results in Table 3 indicate that there was a clear difference in the milk progesterone concentrations in pregnant and non-pregnant animals. Concentrations of progesterone rose 
steadily in the pregnant animals with the advance of pregnancy, while those in the non-pregnant animals decreased.

\section{Pregnancy test}

The animals selected for this study were classified as pregnant or non-pregnant on the basis of their milk progesterone levels. Those with $<7 \mathrm{ng}$ progesterone $/ \mathrm{ml}$ were considered to be nonpregnant. The results are shown in Table 4. Animals diagnosed as non-pregnant were checked by physical examination and whether they returned to oestrus. The test was completely efficient for detection of non-pregnant animals, but was less successful for pregnant buffaloes, being 65$83 \%$ correct. The accuracy at Day 28 was nearly as good as that at Day 40.

Table 3. Concentrations (mean \pm s.e.m.) of progesterone in milk (full-milk evening) samples (no. in parentheses) of pregnant and non-pregnant buffaloes at various times after insemination

\begin{tabular}{ccc}
\hline \multirow{2}{*}{$\begin{array}{c}\text { Day after } \\
\text { insemination }\end{array}$} & \multicolumn{2}{c}{ Progesterone $(\mathrm{ng} / \mathrm{ml})$} \\
\cline { 2 - 3 } & Pregnant & Non-pregnant \\
\hline 20 & $24.8 \pm 3.9(21)$ & $2.9 \pm 1 \cdot 3(24)$ \\
24 & $27.5 \pm 3.4(19)$ & $2.5 \pm 1 \cdot 1(23)$ \\
28 & $28.5 \pm 2.7(22)$ & $2.4 \pm 1.0(26)$ \\
40 & $32.4 \pm 4.2(20)$ & $1.8 \pm 0.6(28)$ \\
\hline
\end{tabular}

Table 4. Diagnosis of pregnancy in buffalo cows from progesterone concentrations in milk samples

\begin{tabular}{|c|c|c|c|c|c|}
\hline \multirow{2}{*}{$\begin{array}{c}\text { Day after } \\
\text { insemination }\end{array}$} & \multirow{2}{*}{$\begin{array}{l}\text { No. of } \\
\text { cows } \\
\text { tested }\end{array}$} & \multicolumn{2}{|c|}{ Predicted pregnant* } & \multicolumn{2}{|c|}{ Predicted non-pregnant ${ }^{\dagger}$} \\
\hline & & Total & Correct (\%) & Total & Correct $(\%)$ \\
\hline 20 & 56 & 32 & $21(65 \cdot 6)$ & 24 & $24(100)$ \\
\hline 24 & 51 & 28 & $19(67.9)$ & 23 & $23(100)$ \\
\hline 28 & 53 & 27 & $22(81.5)$ & 26 & $26(100)$ \\
\hline 40 & 52 & 24 & $20(83 \cdot 3)$ & 28 & $28(100)$ \\
\hline
\end{tabular}

* Milk progesterone concentration of $>7 \mathrm{ng} / \mathrm{ml}$.

$\dagger$ Milk progesterone concentration of $<7 \mathrm{ng} / \mathrm{ml}$.

\section{Discussion}

It is clear that most of the progesterone in buffalo milk is associated with the milk fat. Heap \& Laing (1974) reported that the progesterone concentration of cow milk could be related to fat content of the milk in that $75 \%$ of the hormone was present in the fat and $25 \%$ in casein. Our results for buffalo are in good agreement with the values reported by Heap et al. (1976) and Pennington et al. (1976) for cows.

The progesterone concentrations in buffalo milk are in agreement with those of Hoffman, Gunzler, Hamburger \& Schmidt (1976) for cow milk, although Heap et al. (1976) suggested that the values obtained for progesterone in milk may be over-estimates because of the presence of metabolites of progesterone which might cross-react with the antiserum. The difference in the milk progesterone levels in gravid and non-gravid animals was reported earlier by several workers (Dobson \& Fitzpatrick, 1976; Gunzler \& Hamburger, 1976; Lamming \& Bulman, 1976). 
Successful diagnosis of non-pregnant buffaloes was possible by Day 20 after insemination, and the success rate of pregnancy diagnosis is similar to the values obtained for cows (Heap et al., 1976; Hoffman et al., 1976; Pennington et al., 1976; Koefoed-Johnsen, 1976). The error arising from false positive observations at Day 20 and Day 24 after insemination was substantial. The occurrence of false positive predictions, related to high ( $>7 \mathrm{ng}$ progesterone $/ \mathrm{ml}$ ) milk progesterone concentrations even at 4 weeks after insemination, is probably due to embryonic loss as reported for lactating cows (Pope \& Hodgson-Jones, 1975; Heap et al., 1976).

We thank Mr P. A. Sarma for providing the palpation data, Mr S. Singh for statistical analysis, and Dr N. C. Ganguli, Division of Dairy Chemistry, N.D.R.I., and Dr D. Sundaresan, N.D.R.I., Karnal, for providing the necessary facilities and the keen interest in the work.

\section{References}

Dobson, H. \& Fitzpatrick, R.J. (1976) Clinical Application of the progesterone in milk test. Br. vet. J. 132, 538-542.

Gunzler, O. \& Hamburger, R. (1976) Practical experience in Baroria with fertility testing by progesterone determination in milk. Tierzüchter 28, 175-176. [Cited in Dairy Sci. Abstr. (1976) 38, No. 7222.]

Heap, R.B. \& Laing, J.A. (1974) Pregnancy diagnosis in cows: progress report on the use of progestagen concentration in milk. Br. Cattle Breeders Club, Digest No. 29, 27-29.

Heap, R.B. \& Linzell, J.L. (1966) Arterial concentration, ovarian secretion and mammary uptake of progesterone in goats during the reproductive cycle. $J$. Endocr. 36, 389-99.

Heap, R.B., Linzell, J.L. \& Slotin, C.A. (1969) Quantitative measurement of progesterone metabolism in the mammary gland of the goat. J. Physiol., Lond. 200, 38-40.

Heap, R.B., Gwyn, M., Laing, J.A. \& Walters, D.E. (1973) Pregnancy diagnosis in cows: changes in milk progesterone concentration during the oestrous cycle and pregnancy measured by a rapid radioimmunoassay. J. agric. Sci., Camb. 81, 151-157.

Heap, R.B., Bedford, C.A. \& Linzell, J.L. (1975) Metabolic clearance rate, production rate and mammary uptake of progesterone in the goat. J. Endocr. 64, 485-502.

Heap, R.B., Holdsworth, R.J., Gadsby, J.E., Laing, J.A. \& Walters, D.E. (1976) Pregnancy diagnosis in the cow from milk progesterone concentration. Br. vet.J. $132,445-463$.

Hoffmann, B., Gunzler, O., Hamburger, R. \& Schmidt, W. (1976) Milk progesterone as a parameter for fertility control in cattle; methodological approaches and present status of application in Germany. $B r$. vet. $J$. 132, 469-476.

Indian Standards Institution (1958) Determination of fat in milk. No. 1324.

Koefoed-Johnsen, H.H. (1976) Reproduction control in cattle by means of milk progesterone assay. Asberetn. Inst. Sterilitesforskning B1-B12 [Cited in Dairy Sci. Abstr. (1977) 39, No. 854]

Laing, J.A. (1976) Progesterone assays of milk and the control of infertility. Br. vet.J. 132, 534-537.

Laing, J.A. \& Heap, R.B. (1971) The concentration of progesterone in the milk of cows during the reproductive cycle. $B r$. vet. $J$. 127, xix-xxii.

Lamming, G.E. \& Bulman, D.C. (1976) The use of milk progesterone radioimmunoassay in the diagnosis and treatment of subfertility in dairy cows. Br. vet. J. 132, 507-517.

Pennington, J.A., Spahr, S.L. \& Lodge, J.R. (1976) Pregnancy diagnosis in dairy cattle by progesterone concentration in milk. J. Dairy Sci. 59, 1528-1531.

Pope, G.S. \& Hodgson-Jones, L.S. (1975) Use of plasma progesterone levels in an assessment of embryonic loss in dairy cattle. Vet. Rec. 96, 154.

Pope, G.S., Majzlik, I., Ball, P.J.H. \& Leaver, J.D. (1976) Use of progesterone concentration in plasma and milk in the diagnosis of pregnancy in domestic cattle. Br. vet. J. 132, 497-506.

Schiavo, J.J., Matuszczak, R.L., Oltenacu, E.B. \& Foote, R.H. (1975) Milk progesterone in postpartum and pregnant cows as a monitor of reproductive status. $J$. Dairy Sci. 58, 1713-1716.

Thibier, M. (1974) Progesterone in cows milk: early pregnancy diagnosis. Elevage Insemination 144, 2732. [Cited in Dairy Sci. Abstr. (1976) 38, No. 7223.] 